\title{
The Construction of Meghan Markle's Identity as a Biracial Woman in Media Reports
}

\author{
$1^{\text {st }}$ Maghfirah Fitrianur Ardifa \\ English Studies Program, Faculty of \\ Humanities \\ Universitas Indonesia \\ Depok, Indonesia \\ maghfirah.fitrianur@ui.ac.id
}

\author{
$2^{\text {nd }}$ Harumi Manik Ayu Yamin* \\ Linguistics Department, Faculty of \\ Humanities \\ Universitas Indonesia \\ Depok, Indonesia \\ harumi.m@ui.ac.id
}

\begin{abstract}
The construction of Meghan Markle's identity as a biracial woman can be represented through the reports on the British royal wedding in 2018 in some UK and US media outlets. However, the wedding of Prince Harry and Meghan Markle became a controversy since Harry was the only royal family member to marry a mixed-race woman. Media outlets around the world reporting on their marriage mostly focused on Meghan's racial identity. This research focuses on how and why race relations became commonly highlighted issue in the media coverage, especially they relate to racial identity. The significance of this research is to provide a critical perspective toward a globally known cultural event. The theory of modern racism proposed by Caliendo and McIlwain (2015) [1] and Paltridge's (2006) [2] critical discourse analysis and framing serve as the framework for this research. Furthermore, since some media outlets in the UK and the US are dominated by white people who want to maintain their existence, there is ambivalence in the media regarding her presence and whether she presents a new image of the British royal family or is a biracial woman who does not significantly impact how biracial people are represented in the media.
\end{abstract}

Keywords-Biracial identity, African-American, British Royal family, Media

\section{INTRODUCTION}

People around the world look forward to royal weddings as memorable historical events. However, the 2018 British royal wedding was an uncommon event in the royal family. Prince Harry married Meghan Markle, a biracial American woman. Since the British royal wedding always attracts a great deal of media attention around the world, Harry and Meghan's wedding highlighted the way the media covered race-related issues. Journalists not only brought up Meghan's racial background but also her family background. Meghan's parents, Doria Ragland and Thomas Markle divorced each other when Meghan was six years old. Meghan's mother is African American, while Thomas is Dutch-Irish.

On November 27, 2017, Meghan and Harry confessed to the media that they got engaged at the beginning of the month and would celebrate their royal wedding on May 19, 2018, in St. George's Chapel at Windsor Castle. The prominent UK media sources that reported on their wedding were the Daily Express, TIME, The Sun, the Daily Mail newspaper, and Glamour. Another media outlet from the United States, The Washington Post, also covered the wedding extensively. Some of those media reports on the 2018 royal wedding event still seem quite racist in their treatment of the Duchess of Sussex. The British royal wedding can be considered as a product of popular culture because many people around the world enjoyed it, and the event was a representation of political power, a power held by a group or an individual to influence people, enabling the royal family to utilize public resources due to their prominence. Aside from Williams' statement, the royal wedding has never been a wedding in the traditional sensea celebration of the union between lovers - but a worldwide entertainment event with its own political purposes (e.g., to create an image of the UK as a regal, lavish, and civilized country).

Meghan Markle's biracial identity has become a problem because there are pros and cons regarding whether or not the wedding will change the racial relationship between white and black people in Britain. Plenty of research has been conducted on mixed-race identity and its depiction in the media. Cooley et al. [4] argued that biracial people are often seen as black instead of mixed-race in order to maintain the existing hierarchy of whites, which is called "hypodescent." This concept strengthens the existing racial hierarchy by emphasizing differences among racial groups and establishing a firm definition of who is and is not appropriately considered as white. Yancey [5] also confirmed that someone of African descent or pure AfricanAmerican heritage might have to deal with more racial stigma than other racial minorities. He also stated that people could face racial stigma if they marry someone of a different race or ethnicity. Similarly, Edison [6] analyzed this phenomenon and found that, historically, biracial people have been depicted as tragic "mulattos" and experienced different developmental processes than monoracial individuals. Besides the issue of identity, the UK media has also played a significant role regarding the British royal wedding (2018). Therefore, the media has a significant role in shaping identity and creating stereotypes. Acceding to Yancey [5], stereotypes of African-American in the media could also happen because "African-Americans suffer from a unique form of alienation that makes it difficult for them to enter into the societal mainstream."

While the presence of Meghan Markle in the British royal family and her identity as a biracial woman (of African-American descent) has become a controversy in certain aspects of the media coverage, this article discusses how race relations became an issue that is mostly highlighted in the media coverage, especially when it comes to racial identity. Moreover, bias, disempowerment, and discrimination regarding race have been longstanding issues within several aspects of the mainstream media, including television news, entertainment, and advertising" [7]. Therefore, to explain the topic of media construction in 
relation Meghan Markle's identity in more detail, the author of this article investigated the constructions of Meghan Markle's public identity as a biracial person in terms of her physical appearance, family background, and the way journalists report on Meghan Markle's life as a royal family member in comparison with Kate Middleton as a white woman who also became a royal family member.

\section{METHODOLOGY}

This article features a qualitative method applied through library research from online and offline sources (i.e., news, magazine, and articles) by using Paltridge's [2] critical discourse analysis framing and identity, as well as Caliendo and McIlwain's [1] modern racism theory as a framework for the analysis of the construction of Meghan Markle's identity. According to Paltridge [2], critical discourse analysis explains the connections between the use of language and the political and social contexts in which it occurs. The critical discourse analysis covers some issues, such as ethnicity, gender, ideology and identity, cultural differences, and how these issues are constructed and portrayed in texts. In addition, in this research, the theory of modern racism in mass media was used to determine the presence of racism behind the media reports on Meghan Markle's identity as a biracial African-American woman and to examine its impacts on the discourse on race.

A. Ambivalence in the media coverage of Meghan Markle's presence in the royal family

Table 1. Media Reports on Meghan's Presence in the Royal Family

\begin{tabular}{|c|c|c|c|}
\hline Time (2018) & The Sun (2018) & $\begin{array}{c}\text { Daily Express } \\
(2018)\end{array}$ & $\begin{array}{c}\text { The Washington } \\
\text { Post (2018) }\end{array}$ \\
\hline $\begin{array}{l}\text { Meghan } \\
\text { Markle can } \\
\text { make the } \\
\text { royal family } \\
\text { more } \\
\text { "modern." }\end{array}$ & $\begin{array}{l}\text { Meghan's } \\
\text { presence in the } \\
\text { royal family does } \\
\text { not really } \\
\text { "modernize" the } \\
\text { royals because she } \\
\text { could alienate the } \\
\text { royalists. }\end{array}$ & $\begin{array}{l}\text { "The Queen's } \\
\text { decision to allow } \\
\text { Prince Harry to } \\
\text { marry Meghan } \\
\text { Markle shows how } \\
\text { she is set on } \\
\text { modernizing the } \\
\text { royals." }\end{array}$ & $\begin{array}{l}\text { "It's not } \\
\text { 'modern' to } \\
\text { have a black or } \\
\text { mixed-race } \\
\text { person in the } \\
\text { royal family or } \\
\text { aristocratic } \\
\text { society. If } \\
\text { Britain and its } \\
\text { royal family } \\
\text { truly want to be } \\
\text { modern, it's } \\
\text { time that the } \\
\text { United a } \\
\text { Kingdom as a } \\
\text { nation fully } \\
\text { acknowledges } \\
\text { its past with } \\
\text { black and } \\
\text { brown people." }\end{array}$ \\
\hline
\end{tabular}

Time and the Daily Express did not focus on Meghan's identity as a biracial woman. As displayed in Table 1, the statements indicate that Time and the Daily Express see the British royal family as something that is old fashioned and has to be changed. Furthermore, by using the word "modern" in the reports, Time and the Daily Express did not cover Meghan based on her identity as a biracial woman but valued her for her ability to change the old institutional order. By positioning Meghan Markle as a modern woman, both media outlets framed the British royal family as something old that needs to be modernized.
While Time and the Daily Express put forth positive sentiments, The Sun had a different perspective regarding Meghan Markle. As seen in Table 1, The Sun used the word "alienate" in its report. The word "alienate" itself has a negative connotation that implies that royalists (the predominantly white members of the British royal family) are alienated from the family. Here, The Sun's report suggests that Meghan Markle did something wrong toward the royalists merely because of her different background. Thus, although The Sun does not explicitly focus on the race issue, the coverage deals with Meghan Markle based on her racial identity as a woman of color.

Different from Time, the Daily Express, and The Sun, The Washington Post's coverage sends a more ambiguous message (see Table 1). It seems that The Washington Post sided with other media outlets that were both in favor and also against Meghan's presence. The first sentence- - "It's not modern to have black or mixed-race person in the royal family or aristocratic society"- does not have a negative connotation because it seems that it should be treated as a normal royal wedding. However, in the second sentence, Meghan Markle is not considered as "modernizing" the British royal family because, to be "modern," the British royal family must make significant changes in terms of race relations by acknowledging their history with black people. Here, The Washington Post also refrained from attacking Meghan Markle's identity as a biracial woman. Therefore, The Washington Post's report has an ambivalent message because they do not see Meghan Markle as a transformative force within the royal family.

Moreover, although the terms "ambiguous" and "ambivalence" appear frequently in this article, they actually have slightly different meanings. According to MerriamWebster's Dictionary [8], “ambivalence associates with multiple and contradictory feelings, while ambiguous often describes something with several possible meanings that create uncertainty."

Therefore, from the explanation above, Meghan's identity as a biracial woman is still questioned regarding whether her identity can be considered as a transformative force within the British royal family or not. On one side, Meghan is represented as "fresh air" for the royal family, but at the same time, she is portrayed improperly in the media regarding her biracial identity.

\section{B. Meghan versus Kate: Problematizing racial background in media portrayals}

Table 2. Comparison of the Daily Mail's Reports on Meghan and Kate

\begin{tabular}{l}
\hline \multicolumn{3}{c}{ Daily Mail (2011) } & \multicolumn{1}{c}{ Daily Mail (2016) } \\
\hline It was good for Kate as a Prince Harry's wife is (almost) \\
commoner to marry Prince \\
William.
\end{tabular}

As indicated in the table above, the UK media (the Daily Mail) tends to highlight the racial background of Meghan in their articles just because she is biracial or a half-black woman. However, when it comes to Kate, articles on British media do not always consider her as a white person. As reported in the Daily Mail, it was good for Kate, as a commoner, to marry William. However, when it comes to Meghan, the author that "Meghan is (almost) straight outta 
Compton" (Daily Mail, 2016). The report might not seem racist, but it indirectly aims to convey that Meghan Markle is a woman of color by saying that she comes from Compton. In this case, it can be seen that the media reports on Kate differ from those on Meghan Markle. Kate is only depicted as a commoner, and the media did not make her race an issue when she married Prince William. Meanwhile, the Daily Mail's reports on Kate do not mention her race and focus on her upbringing instead, which suggests that the media is upholding a subtle form of white supremacy. By disassociating Kate from her race, the implication is that being white is considered as "the norm"- that is, being white is the only acceptable racial status in society. In other words, races other than white are considered inferior. Meghan's presence in the British royal family is considered to be a violation of "the norm"; hence, Meghan is always mentioned as "a biracial or African-American woman" instead of just "a woman" or according to her occupation (e.g., a "celebrity," "activist," etc.)

Compton today is currently known for its gang influence, successful rappers, and racial divisions. Gang violence has continued to harm Compton's reputation [9]. Compton also comes with other negative connotations. Compton activist Hays said, "Drugs have pillaged black and brown communities. It makes our neighborhoods a bad place to live in" [10]. Therefore, Compton symbolizes a black neighborhood rife with gangsters, criminals, police harassment, and poor people.

Even though Meghan Markle is biracial, some media outlets still consider her as a black woman. Cooley et al. [4] argued that biracial people are often seen as being black, which maintains the existing racial hierarchy by accentuating divisions between racial groups and creating a strict definition of who is (and is not) classified as white. Moreover, biracial people are often classified into a single racial category - a racial category that represents their socially marginalized identity (categorizing a mixed-race individual as a minority group member). From Table 2 and the explanation above, one can conclude that the Daily Mail painted Meghan Markle as a typical "hood person" due to racism in its modern form. Modern racism is a kind of hostility, rejection, and denial toward black aspirations (Entman, 1992) [3]. If the reports on Meghan Markle in Table 2 are linked to the theory of modern racism, Meghan Markle as a woman of color is portrayed by mass media as a "fringe" figure [7]. In other words, media outlets describe her as an alienated woman due to her biracial identity.

Those reports on Meghan and Kate show that racial difference had a visible role in the media coverage of Meghan and Harry's wedding compared to Kate and William's royal wedding in 2011 .

\section{Meghan's family: Highlighting racial inheritance}

Table 3 Meghan's Family: Highlighting Racial Inheritance

GLAMOUR (2018) The Sun (2018)

"Meghan Markle is an American "[H]er mother is black with woman, a daughter to a black dreadlocks, and she passes as mother and a white father, a Caucasian[;] she often received descendant of those enslaved and hurtful comments about whether those who were always free."
Doria was her real mum."

"Being biracial paints a blurred line that is equal parts staggering and illuminating" (Elle as cited in The Sun, 2018).
From Table 3, it can be seen that Glamour tends to take a racist stance toward Doria, even in the media. Media outlets have also paid attention to the background of Meghan's mother, emphasizing her racial inheritance by noting that one is black and the other is white. Moreover, by stating that she is "a descendant of those enslaved," the article is not only highlighting her racial inheritance based on her parent's background but also the image of slavery. Such forms of racial stigma may happen in instances of interracial or interethnic marriage [5], which is what happened to Meghan and Harry. Their wedding became controversial because of their racial differences.

The black skin tone that Meghan's mother has exposes both Meghan and Doria to racism. For instance, another article (The Sun, 2018) focuses on how Meghan and her family faced racism when she was younger due to Doria's racial background. The article demonstrates that the different skin tones of Meghan's parents have led to racism being projected toward Meghan. Yancey [5] stated that mixed-race people may have to deal with racial stigma compared to other racial minorities, especially for those who have African-American heritage or pure African-American blood. Therefore, The Sun's reports about Doria also constitute a kind of racial stigmatization. Moreover, The Sun used the word "dreadlocks," which has a somewhat pejorative meaning, to describe Meghan's mother. According to West [11], some words generate negative connotations toward those who possess dreadlocks or afro-textured hair, which are "nappy" and "bushy." In the 1800s, these words were commonly used by slave owners to describe their slaves' hair. Here, the media report from The Sun displayed in Table 3 can also be analyzed by using Paltridge's [2] critical discourse analysis by looking at the choice of word used when reporting on Meghan. The choice of the word "dreadlocks" serves to create a certain image of Doria, which refers to Doria as a native African-American woman (black). Moreover, using the word "dreadlocks" affects Meghan's identity in the mass media by depicting her as a biracial woman.

Apart from Doria, Thomas Markle's racial inheritance as a white man also affects Meghan Markle's biracial identity. Thomas Markle is a British-Irish man. According to the analysis above, his racial background also traps Meghan Markle in a gray area. She is too light to be called black but also too dark to be called white. In The Sun (2018), quoted from Elle, Meghan said, "Being biracial paints a blurred line that is equal parts staggering and illuminating." Even so, Edison [6] argued that, although biracial people are considered to be black, they now have the right to choose their racial identity. Nevertheless, Meghan made the decision to remain biracial, and she is proud of it.

\section{CONCLUSION}

To conclude, international reports that reflect how the media has reported on this marriage and its racial elements come from The Washington Post, the Daily Express, Time, The Sun, Heavy, the Daily Mail, and Glamour. Their reports shed light on how media outlets construct Meghan's identity. 
From the findings, it is apparent that some media reports on the 2018 British royal wedding express racist attitudes regarding Meghan Markle just because she is biracial, and some reports are rather ambiguous on this topic.

Among the six media outlets analyzed in this research, two express positive sentiments, such as those in Time and the Daily Express, which did not allude to race. In essence, their reports suggest that Meghan may be able to modernize the British royal family because her presence may make the royal family more open to accepting people of color in their "white" institution. However, a larger number of media reports still feature outdated racist stereotypes in their depictions of Meghan, represented by those in The Sun, the Daily Mail, and Glamour. Meanwhile, The Washington Post's reporting on this topic is slightly ambiguous. In The Washington Post's reports, it is said that, if Britain and the royal family want to be "modern," they have to acknowledge their past with black people. Thus, mainstream media outlets still have racist attitudes about biracial people of mixed African-American blood.

At first glance, the royal wedding may appear as a mere popular culture product that was only designed to entertain people, potentially making it a trivial subject for serious academic examination. However, this research provides a critical perspective on a globally known cultural event, which is important because popular culture has the power to influence public perceptions of societal values, norms, and other issues, such as race. While this article may provide an alternative perspective on the royal wedding as a product of popular culture, the identity issue is still predominantly viewed through the lens of race. Therefore, the importance of how the issue intersects with other issues, such as the possible ways people receive, internalize, and articulate biased media reports, must not be overlooked. Finally, there needs to be more critical research in the future to examine how media outlets report on interracial marriage, especially the marriages of famous or prominent society figures that can influence the way society sees those individuals.

\section{Acknowledgments}

We would like to thank Universitas Indonesia for providing the academic platform for us to conduct our research and share the findings in an international conference at the Faculty of Humanities, Universitas Indonesia.

\section{References}

[1] Caliendo, S. M., \& McIlwain, C. D. (2014). Effects of levels of implicit association, symbolic racism, and explicit racial resentment on evaluation of white and black candidates.

[2] Paltridge, B. (2006). Critical Discourse Analysis. In Discourse Analysis (pp. 187-189). London: Continuum.

[3] Entman, R. M. (1992). Blacks in the News: Television, Modern Racism and Cultural Change. Journalism Quarterly.

[4] Cooley, E., Brown-Iannuzzi, J. L., Brown, C. S., \& Polikoff, J. (2017). Black groups accentuate hypodescent by activating threats to the racial hierarchy. Social Psychological and Personality Science, 9(4), 411-418. doi:10.1177/1948550617708014.

[5] Yancey, G. (2007). Differences in the experiences of whites married to blacks and non-black racial minorities, 197-213.

[6] Edison, A. (2007). The impact of the media on biracial identity formation, 1-93.

[7] Kulaszewicz \& Kassia, E. (2015). Racism and the media: A textual analysis. Retrieved from Sophia, the St. Catherine University repository website: https://sophia.stkate.edu/msw_papers/477.

[8] Merriam-Webster's Collegiate Dictionary (11th ed.). (2003). Springfield, Merriam-Webster.

[9] Thompson, L. (2018). Compton: Giving Back to the Community. Retrieved from http://www.compton.edu/academics/div3/humanities/VOC2018_Com plete.pdf.

[10] Judge, M. (2018). Black People Don't Want 'the Chronic' in Compton, Calif. Retrieved from https://www.theroot.com/black-people-don-twant-the-chronic-in-compton-1822747733.

[11] West, W. (1922). History of the American People. Boston, MA.: Allyn and Bacon. 